\title{
ANALISIS DASAR HUKUM KEBIJAKAN PEMERINTAH DALAM MENANGANI PANDEMI COVID 19
}

\author{
Muhamad Rusjana $^{1}$, Diasti Rastosari ${ }^{2}$ \\ Universitas Sang Bumi Ruwa Jurai \\ Muhamadrusjana@gmail.com
}

\begin{abstract}
Abstrak
Pemerintah Indonesia diawal kemunculan covid 19 tetap membuka lebar lalu lintas pintu masuk ke Indonesia. Awal maret 2020 pemerintah telah mengkonfirmasi adanya infeksi covid 19, hingga kini jumlah korban jiwa dan penularan covid 19 semakin meluas dan naik tanpa adanya penurunan. Ketidakseriusan pemerintah dalam menangani covid 19 terlihat pada beberapa istilah misalnya lockdown, social distancing, physical distancing sampai dengan penggunaan istilah karantina yang tidak konsisten juga penggunaan istilah bagi orang yang terinfeksi covid 19 yaitu orang dalam pemantauan (ODP), pasien dalam pengawasan (PDP) sampai dengan orang tanpa gejala (OTG). Penggunaan istilah-istilah tersebut dapat simpulkan bahwa pemerintah tidak mampu mengidentifikasi orang yang terinfeksi covid 19 dengan alat yang dimilikinya. Metode penelitian dalam penelitian ini menggunakan Jenis penelitian hukum normatif dengan mengutamakan data sekunder. Metode pendekatan dalam penelitian ini menggunakan pendekatan peraturan perundag-undangan (statute approach). Jenis data dalam penelitian ini yaitu data sekunder yang terdiri atas bahan hukum primer berupa peraturan perundang-undangan yang berkaitan dengan objek penelitian, bahan hukum sekunder yaitu merupakan literature kepustakaan yang berkaitan dan bahan hukum tersier yaitu pendukung atas bahan hukum primer dan sekunder. Teknik pengumpulan data dalam penelitian ini adalah melalui studi pustaka atau dokumenter yaitu melalui penelitian bahan kepustakaan (library reseach). Analisis data pada penelitian ini data pustaka yang diperoleh terhadap bahan-bahan primer, sekunder dan tersier dianalisa secara kualitatif deskriptif.
\end{abstract}

Kata Kunci: Kebijakan, Pemerintah, Covid 19.

\begin{abstract}
The Indonesian government at the beginning of the emergence of COVID-19, the entrance to Indonesia remained open. In early March 2020, the government has confirmed the existence of Covid 19 infection, until now the number of fatalities and transmission of Covid 19 is expanding and increasing without any decline. The government's lack of seriousness in covid 19 is seen in several terms such as lockdown, social distancing, physical distancing to the inconsistent use of the term quarantine as well as the use of terms for people infected with Covid 19, namely people under surveillance (ODP), patients under surveillance (PDP) to people without symptoms $(O T G)$. The use of this term can conclude that the government is unable to identify people infected with Covid 19 with the tools they have. The research method in this research uses normative legal research by prioritizing secondary data. The method of approach in this research uses a statutory approach (statute approach). The type of data in this research is secondary data which consists of primary legal materials in the form of regulations relating to the object of research, secondary legal materials, namely literature related to tertiary legal materials, namely supporting primary and secondary legal materials. The data technique in this research is through library research or documentary, namely through library research (library research). Analysis of the data in this study library data obtained on primary, secondary materials and descriptive qualitative analysis.
\end{abstract}

Keywords: Policy, Government, Covid 19.

\section{PENDAHULUAN}

Virus Corona yang selanjutnya oleh WHO disebut sebagai Covid 19 pertama kali ditemukan di Wuhan Tiongkok menimbulkan banyak korban hingga menimbulkan kegelisahan masyarakat dunia, pasalnya karakter covid 19 ini sangat mematikan serta 
penyebaran dan indikasinya sangat luas. Menyikapi hal tersebut beberapa negara di dunia dengan sigap menyiapkan strategi penanganan covid 19, seperti halnya yang dilakukan oleh Malaysia dan Korea Selatan yang secara tegas melarang warga negaranya bepergian ke Tiongkok hingga memperketat pintu masuk lalu lintas ke negaranya. Berbeda dengan Pemerintah Indonesia diawal kemunculan covid 19 sangat optimis meyakinkan masyarakat bahwa Covid 19 tidak semudah itu untuk masuk ke Indonesia karena kondisi cuaca yang cenderung panas serta Masyarakat Indonesia memiliki imunitas yang baik sehingga kebal terhadap covid 19.

Awal maret 2020 pemerintah telah mengkonfirmasi adanya infeksi covid 19 yang sekaligus mematahkan pernyataan pemerintah terhadap kekebalan covid 19. Covid 19 telah menyebar keseluruh wilayah di Indonesia dan pemerintah mulai membuka mata bahwa covid 19 merupakan ancaman yang nyata, hingga kini jumlah korban jiwa dan penularan covid 19 semakin meluas dan naik tanpa adanya penurunan.

Selanjutnya Ketidakseriusan Pemerintah Indonesia dalam menangangi covid 19 terlihat pada beberapa istilah misalnya lockdown, social distancing, physical distancing sampai dengan penggunaan istilah karantina yang tidak konsisten juga penggunaan istilah bagi orang yang terinfeksi covid 19 yaitu orang dalam pemantauan (ODP), pasien dalam pengawasan (PDP) sampai dengan orang tanpa gejala. Penggunaan istilah-istilah tersebut dapat simpulkan bahwa pemerintah tidak mampu mengidentifikasi orang yang terinfeksi covid 19 dengan alat yang dimilikinya. Berbicara mengenai karantina kesehatan seharusnya pemerintah mendasarkan pada Undang-undang Nomor 6 Tahun 2018 tentang Kekarantinaan Kesehatan, sebagaimana telah terdapat istilah karantina yang diatur pada pasal 49. Beberapa kebijakan pemerintah yang membingungkan sebagaimana telah dipaparkan di atas, tentu ini yang mendasari penulis untuk mengkaji lebih lanjut mengenai analisis dasar hukum kebijakan pemerintah dalam menangani covid 19, dengan mengkaji beberapa asas-asas dalam pembentukan peraturan perundang-undangan, literatur kepustakaan yang berkaitan selanjutnya guna memberikan sumbangan pemikiran bagi pejabat pemerintah.

Berangkat pada permasalahan pandemic covid 19 yang belum usai hingga menimbulkan banyak permasalahan terutama dalam menekan dan/atau menghentikan laju penyebaran covid 19, penulis mencoba mengkaji mengenai dasar hukum kebijakan pemerintah dalam menangani pandemic covid 19 yang masih belum serius dalam menangani pandemic covid terindikasi dari jumlah korban yang terus meningkat serta laju penyebaran yang semakin meluas. Selanjutnya peneliti mencoba untuk memberikan sumbangan pemikiran berupa dasar hukum pembentukan kebijakan ditinjau dari beberapa asas dalam pembentukan peraturan perundang-undangan serta teori-teori yang berkaitan.

Tujuan dari penelitian ini adalah guna mengetahui dan memahami dasar hukum kebijakan pemerintah dalam menangani Pandemi Covid 19, serta mengkaji dan menganalisis mengenai kebijakan pemerintah dalam menangani Pandemi Covid 19. Manfaat dan kegunaan penelitian terbagi atas teoritis dan praktis. Secara teoritis tentunya hasil dari penelitian ini diharapkan dapat mengembangkan bidang keilmuan hukum pada umumnya dan hukum administrasi negara khususnya mengenai dasar pembentukan kebijakan, serta dapat memberikan sumbangan pemikiran bagi para peneliti selanjutnya. Secara praktis diharapkan dapat memberikan sumbangan pemikiran, masukan-masukan terutama bagi pejabat pemerintah. 


\section{METODE PENELITIAN}

Jenis penelitian ini merupakan penelitian hukum normatif, karena penelitian hukum yang dilakukan oleh penulis mengutamakan data sekunder. Metode pendekatan dalam penelitian ini menggunakan pendekatan peraturan perundag-undangan (statute approach). Jenis data dalam penelitian ini yaitu data sekunder yang terdiri atas bahan hukum primer berupa peraturan perundang-undangan yang berkaitan dengan objek penelitian, bahan hukum sekunder yaitu merupakan literature kepustakaan yang berkaitan dan bahan hukum tersier yaitu pendukung atas bahan hukum primer dan sekunder.

Teknik pengumpulan data dalam penelitian ini adalah melalui studi pustaka atau dokumenter yaitu melalui penelitian bahan kepustakaan (library reseach), dengan alat pengumpulan data berupa bahan-bahan tertulis seperti peraturan perundang-undangan, putusan pengadilan, literatur buku maupun karya ilmiah lainnya yang terkait dengan permasalahan dalam penelitian. Adapun studi kepustakaan dilakukan di Perpustakaan Fakultas Hukum Universitas Sang Bumi Ruwa Jurai, Perpustakaan Universitas Lampung dan Perpustakaan Daerah Lampung. Analisis data pada penelitian ini data pustaka yang diperoleh terhadap bahan-bahan primer, sekunder dan tersier dianalisa secara kualitatif deskriptif.

\section{HASIL DAN PEMBAHASAN}

\section{Pandemi Covid 19}

Coronavirus merupakan suatu kelompok virus yang dapat menyebabkan penyakit pada hewan atau manusia. Beberapa jenis coronavirus diketahui menyebabkan infeksi saluran nafas pada manusia mulai dari batuk pilek hingga yang lebih serius seperti Middle East Respiratory Syndrome (MERS) dan Severe Acute Respiratory Syndrome (SARS). Coronavirus jenis baru yang ditemukan menyebabkan penyakit COVID-19. Selanjutnya COVID-19 adalah penyakit menular yang disebabkan oleh jenis coronavirus yang baru ditemukan. Virus baru dan penyakit yang disebabkannya ini tidak dikenal sebelum mulainya wabah di Wuhan, Tiongkok, bulan Desember 2019. COVID-19 ini sekarang menjadi sebuah pandemi yang terjadi di banyak negara di seluruh dunia.

Gejala-gejala COVID-19 yang paling umum adalah demam, batuk kering, dan rasa lelah. Gejala lainnya yang lebih jarang dan mungkin dialami beberapa pasien meliputi rasa nyeri dan sakit, hidung tersumbat, sakit kepala, konjungtivitis, sakit tenggorokan, diare, kehilangan indera rasa atau penciuman, ruam pada kulit, atau perubahan warna jari tangan atau kaki.

Orang-orang lanjut usia (lansia) dan orang-orang dengan kondisi medis penyerta seperti tekanan darah tinggi, gangguan jantung dan paru-paru, diabetes, atau kanker memiliki kemungkinan lebih besar mengalami sakit lebih serius. Namun, siapa pun dapat terinfeksi COVID-19 dan mengalami sakit yang serius. Orang dari segala usia yang mengalami demam dan/atau batuk disertai dengan kesulitan bernapas/sesak napas, nyeri/tekanan dada, atau kehilangan kemampuan berbicara atau bergerak harus segera mencari pertolongan medis. Jika memungkinkan, disarankan untuk menghubungi penyedia layanan kesehatan atau fasilitas kesehatan terlebih dahulu, sehingga pasien dapat diarahkan ke fasilitas kesehatan yang tepat. Orang dapat tertular COVID-19 dari orang lain yang terinfeksi virus ini. COVID-19 dapat menyebar terutama dari orang ke orang melalui percikan-percikan dari hidung atau mulut yang keluar saat orang yang 
terinfeksi COVID-19 batuk, bersin atau berbicara. Percikan-percikan ini dapat menempel di benda dan permukaan lainnya di sekitar orang seperti meja, gagang pintu, dan pegangan tangan. Orang dapat terinfeksi dengan menyentuh benda atau permukaan tersebut, kemudian menyentuh mata, hidung, atau mulut mereka.

\section{Kebijakan Pemerintah dalam Menangani Pandemi Covid ditinjau dari Asas-Asas Pembentukan Peraturan Perundang-Undangan}

Pembentukan peraturan perundang-undangan harus mengutamakan kejelasan tujuan, dalam arti tujuan pembentukan peraturan perundang-undangan tersebut harus jelas, memenuhi keinginan masyarakat banyak agar dapat menciptakan kepastian yang berkeadilan sehingga dapat mendistribusikan manfaat bagi seluruh rakyat Indonesia. Selain itu, konsep lembaga atau pejabat pembentuk peraturan perundang-undangan harus merupakan lembaga yang kredibel, yang diakui secara demokratis oleh masyarakat banyak. Pembentukan peraturan perundang-undangan harus menyesuaikan antara jenis, hierarki, dan materi muatan serta asas yang sesuai dengan dasar pembentukan peraturan perundang-undangan. Asas merupakan dasar atau landasan dalam menentukan sikap dan perilaku. Asas-asas pembentukan peraturan perundang-undangan merupakan dasar pijak bagi pembentukan peraturan perundang-undangan dan penentu kebijakan dalam membentuk peraturan perundang-undangan.

Dalam membentuk peraturan perundang-undangan harus dilakukan berdasarkan asas pembentukan peraturan perundang-undangan yang baik meliputi: kejelasan tujuan, kelembagaan atau pejabat pembentuk yang tepat dan kesesuaian antara jenis, hierarki serta materi muatan yang dapat dilaksanakan dan kedayagunaan serta kehasilgunaan, kejelasan rumusan dan keterbukaan. Di samping itu materi muatan yang dimuat dalam peraturan perundang-undangan harus mencerminkan asas pengayoman, kemanusiaan dan kebangsaan serta kekeluargaan, kenusantaraan, bhinneka tunggal ika, keadilan serta kesamaan kedudukan dalam hukum dan pemerintahan, ketertiban dan kepastian hukum serta keseimbangan, keserasian, dan keselarasan.

Indonesia sebagai sebuah negara yang merdeka dan berdaulat serta merupakan negara hukum sebagaimana telah disebutkan dalam Undang-Undang Dasar Tahun 1945 mempunyai kewajiban untuk melaksanakan pembangunan hukum nasional yang dilakukan secara terencana, terpadu, dan berkelanjutan. Untuk itu pemerintah Republik Indonesia telah menetapkan Undang-Undang Nomor 12 Tahun 2011 tentang Pembentukan Peraturan Perundang-Undangan. Pembentukan peraturan perundangundangan berdasarkan Pasal 1 angka 1 Undang-Undang Nomor 12 Tahun 2011 sebagaimana yang telah diubah dengan Undang-Undang Nomor 15 Tahun 2019 tentang Perubahan atas Undang-Undang Nomor 12 Tahun 2011 tentang Pembentukan Peraturan Perundang-Undangan yang mencakup tahapan perencanaan, penyusunan, pembahasan, pengesahan atau penetapan, dan pengundangan. Lebih lanjut disebutkan dalam Pasal 1 angka 2 Undang-Undang Nomor 12 Tahun 2011 tentang Pembentukan Peraturan Perundang-Undangan bahwa yang dimaksud dengan peraturan perundangundangan adalah peraturan tertulis yang mempunyai norma hukum yang mengikat secara umum dan dibentuk atau ditetapkan oleh lembaga negara atau pejabat yang berwenang melalui prosedur yang ditetapkan dalam peraturan perundang-undangan.

Asas-asas pembentukan peraturan perundang-undangan yang baik antara lain adalah: Peraturan perundang-undangan tidak berlaku surut; Peraturan perundangundangan yang dibuat oleh penguasa yang lebih tinggi, mempunyai kedudukan yang lebih tinggi, hal ini sesuai dengan hierarki perundang-undangan; Peraturan 
perundangundangan yang bersifat khusus menyampingkan peraturan perundangundangan yang bersifat umum; Peraturan perundang-undangan yang berlaku belakangan membatalkan peraturan perundangundangan yang berlaku terdahulu; Peraturan perundang-undangan tidak dapat di ganggu gugat, dalam arti undang-undang merupakan cerminan dari keadilan yang harus diakui kebenarannya oleh semua pihak; dan Peraturan perundang-undangan sebagai sarana untuk semaksimal mungkin dapat mencapai kesejahteraan spiritual dan material bagi masyarakat maupun individu termasuk sebagai sarana untuk memperoleh keadilan.

\section{Dasar Hukum Kebijakan Pemerintah dalam Menangani Pandemi Covid 19}

Penerbitan regulasi dalam rangka penanganan penyebaran Covid 19 merupakan upaya untuk mendukung keberadaan Undang-Undang Nomor 24 Tahun 2007 tentang Penanggulangan Bencana yang menetapkan wabah penyakit sebagai salah satu bencana non-alam yang perlu dikelola potensi ancamannya. Atas regulasi-regulasi tersebut maka upaya-upaya yang saat ini dilakukan adalah:

a. Kebijakan Social Distancing/Physical Distancing

Adanya Social Distancing sejauh ini sangat efektif dalam menghambat penyebaran virus/penyakit, yakni dengan mencegah orang sakit melakukan kontak dekat dengan orang-orang untuk mencegah penularan. Namun melihat fenomena sekarang, nyatanya social distancing masih berbentuk imbauan yang jika tidak dibantu diviral-kan di media sosial akan lebih sedikit mayarakat yang mengetahuinya. Maka dari itu, sebaiknya kebijakan social distancing harus dimuat dalam peraturan pemerintah pengganti undang-undang tentang upaya penanganan wabah Covid-19, yang salah satunya mengatur social distancing adalah kewajiban, jika perlu terdapat penegasan berupa sanksi sesuai hukum positif, agar masyarakat tidak hanya sadar akan pentingnya social distancing tetapi juga menerapkan praktiknya. Hal ini dirasa perlu untuk melakukan pembatasan hak individual dalam melakukan social distancing karena kondisi yang terjadi adalah kegentingan yang mengancam kesehatan publik.

Istilah social distancing kemudian mengalami perubahan menjadi physical distancing sesuai dengan istilah yang digunakan WHO karena penggunaan istilah social distancing seolah-olah melakukan penghentian interaksi sosial dalam masyarakat sementara yang sebenarnya diinginkan hanya menjaga jarak fisik. Dari hal inilah kemudian berbagai aktivitas yang pada awalnya dilakukan dengan jarak fisik yang dekat kemudian diubah menjadi aktivitas yang menciptakan jarak secara fisik antara lain, pembelajaran online (metode daring), penggunaan mekanisme WFH (work from home), penutupan tempat-tempat perbelanjaan (mall) dan upaya lain yang dapat mencegah penyebaran Covid 19.

b. Perlindungan bagi Tenaga Kesehatan sebagai Garda Depan

Tenaga kesehatan berdiri di garda depan dalam mencegah bertambahnya jumlah infeksi sehingga pemerintah perlu menjamin perlindungan dan keselamatan kerja bagi tenaga medis dalam upaya penanganan Covid-19. Perlindungan tenaga kesehatan bergulir setelah ada tujuh dokter meninggal karena positif terinfeksi, kelelahan hingga serangan jantung sehingga dilakukan pengaturan jam kerja, penambahan jumlah rumah sakit rujukan, pemenuhan kebutuhan primer setiap tenaga kesehatan, penyediaan Alat Pelindung Diri (APD), kemudian penentuan skala prioritas pemberian APD. 
Kepastian hukum merupakan instrumen penting dalam menjamin keselamatan tenaga kesehatan sehingga pemerintah tidak dapat melakukan tindakan sewenangwenang terhadap penugasan tenaga kesehatan. Terlebih jika melihat peraturan perundang-undangan mengenai tenaga kesehatan nampaknya belum ada yang mengatur penjaminan kepastian hukum bagi tenaga kesehatan sekalipun sudah ada Undang-undang Nomor 36 Tahun 2014 tentang Tenaga Kesehatan namun saat ini belum ada peraturan pelaksanaan dan petunjuk teknis Undang-undang Tenaga kesehatan dan undang-undang lainnya yang mengatur tentang perlindungan hukum dan keselamatan kerja bagi Tenaga kesehatan.

c. Pembatasan Sosial Berskala Besar

Kewenangan Pembatasan Sosial Bersklala besar berdasarkan Undang-Undang Nomor 6 Tahun 2018 tentang Kekarantinaan Kesehatan merupakan wewenang absolut Pemerintah Pusat. Dalam Pasal 1 Angka 1 dinyatakan bahwa "kekarantinaan kesehatan dilakukan untuk mencegah dan menangkal keluar atau masuknya penyakit dan/atau faktor risiko kesehatan masyrakat yang berpotensi menimbulkan kedaruratan kesehatan masyarakat." Maka dari itu jika ada pemerintah daerah yang merasa daerahnya memiliki situasi kedaruratan dan hendak melakukan lockdown, tentunya hal ini inkonstitusional dan perlu adanya konsul dari kepala daerah dengan pemerintah pusat sebelum mengambil kebijakan terkait. Kemudian atas kondisi darurat penyebaran Covid 19, pemerintah kemudian menetapkan Peraturan Pemerintah No. 21 Tahun 2020 tentang Pembatasan Sosial Berskala Besar dalam rangka Percepatan Penanganan Corona Virus Disease (COVID-19).

Pertimbangan PP No. 21 tahun 2020 tentang Pembatasan Sosial Berskala Besar dalam rangka Percepatan Penanganan Corona Virus Disease (COVID-19) adalah:

1) Bahwa penyebaran Corona Virus Disease 2019 (COVID-19) dengan jumlah kasus dan/atau jumlah kematian telah meningkat dan meluas lintas wilayah dan lintas negara dan berdampak pada aspek politik, ekonomi, sosial, budaya, pertahanan dan keamanan, serta kesejahteraan masyarakat di Indonesia;

2) Bahwa dampak penyebaran Corona Virus Disease 2019 (COVID-19) telah mengakibatkan terjadi keadaan tertentu sehingga perlu dilakukan upaya penanggulangan, salah satunya dengan tindakan pembatasan sosial berskala besar; Peraturan Pemerintah No. 21 tahun 2020 tentang Pembatasan Sosial Berskala Besar dalam rangka Percepatan Penanganan Corona Virus Disease (COVID-19) mengatur tentang Pelaksanaan Pembatasan Sosial Berskala Besar yang ditetapkan oleh Menteri Kesehatan dan dapat dilakukan oleh Pemerintah Daerah berdasarkan persetujuan Menteri Kesehatan. PP 21 tahun 2020 tentang Pembatasan Sosial Berskala Besar dalam rangka Percepatan Penanganan Corona Virus Disease (COVID-19) tentunya diputuskan dengan pertimbangan yang banyak sesuai kultur negara Indonesia. Kebijakan Lockdown tidak menjadi pilihan pemerintah sebagaimana diterapkan di banyak negara, India misalnya menyebabkan chaos dan permasalahan sosial yang mengagetkan. Namun kunci dari hal ini pembatasan diri dan pergerakan individu warga negara untuk tinggal di rumah, membatasi frekuensi dan jumlah pertemuan massal untuk kemudian dapat menaklukan coronavirus pandemi ini.

d. Transparansi pemerintah dalam penanganan pandemi COVID-19

Keterbukaan informasi mengenai Covid 19 menjadi sebuah kemestian saat

ini. Keterbukaan informasi mengenai Covid 19 pada dasarnya mengacu pada UU

No. 14 Tahun 2008 tentang informasi publik menuntut. Pemerintah sebagai badan 
publik untuk membuka secara transparan kasus ini sejak awal. Pada awalnya, informasi mengenai pasien dan data infeksi virus ini tidak terbuka bahkan nama pasien pun dirahasiakan. Alasan pemerintah tidak membuka seluruh informasi terkait penanganan virus korona yang disebabkan karena kekhawatiran menimbulkan kepanikan dan keresahan namun kemudian seiring perkembangan kondisi penyebaran virus ini maka keterbukaan data pun mulai dilakukan karena pemerintah perlu menyampaikan kepada masyarakat data-data pasien yang meninggal atau positif untuk dapat mengetahui rantai penyebaran virus tersebut.

Mengacu pada UU No. 14 tahun 2008, pandemi COVID-19 bukan informasi publik yang dikecualikan oleh Undang-Undang, sebagaimana informasi yang dapat membahayakan negara, karena sejatinya informasi pandemi tersebut sudah diketahui khalayak umum sejak hari pertama mewabah di Wuhan, Tiongkok, dan telah diinformasikan oleh badan kesehatan dunia, WHO. Selanjutnya terdapat ketentuanketentuan yang mewajibkan Pemerintah dan Pemerintah Daerah di luar UU No. 14 Tahun 2008 untuk memberikan informasi sejelas-jelasnya dan membuka akses bagi masyarakat untuk mengetahui informasi tentang kesehatan ataupun penyakit menular, yakni Pasal 17, Pasal 154 dan 155 UU No. 36 tahun 2009. Di samping itu juga, pasal 79 dan 80 UU No. 6 Tahun 2018 tentang Kekarantinaan Kesehatan memberikan landasan otoritas bagi pemerintah pusat dan daerah untuk menyampaikan informasi kekarantinaan kesehatan sebagai bagian dari pencegahan dan pemberantasan risiko kesehatan masyarakat yang dapat menyebabkan kedaruratan.

e. Validitas Data Hasil Pemeriksaan

Pemeriksaan kesehatan terkait dengan Covid 19 dilakukan dengan 2 (dua) cara yaitu rapid test dan swap test dan dari kedua cara ini maka cara kedua merupakan cara yang dianggap paling valid. Tetapi realitas yang kemudian muncul adalah hasil pemeriksaan metode swap test ternyata banyak pula yang menimbulkan masalah karena waktu penentuan hasil pemeriksaan memakan waktu agak lama sehingga beberapa pasien yang meninggal dalam status ODP kemudian setelah dilakukan pemakaman dengan protokol Covid ternyata setelah adanya hasil pemeriksaan, justru negatif. Keterbatasan dalam pemeriksaan metode swap test saat ini menjadi kendala yang besar dalam penanganan Covid 19.

Ditinjau dari aspek hukum, berbagai regulasi telah diterbitkan untuk mencegah penyebaran Covid 19 namun realitas sampai saat ini menunjukkan bahwa belum ada perubahan signifikan dalam penanganan kasus Covid 19 di Indonesia, jumlah pasien semakin bertambah, angka kematian pun semakin melaju. Keberadaan regulasi yang ada tidak akan efektif apabila tidak didukung dengan upaya yang lebih tegas namun santun di dalam masyarakat. Eksistensi dan atensi ekstra dari seluruh pihak terkait menjadi sangat urgen untuk memberikan pemahaman kepada masyarakat mengenai penyebaran virus ini. Kepolisian, aparat pemerintah daerah dari level tertinggi sampai level terendah, aparat TNI, Lembaga-lembaga negara perlu untuk melakukan sosialisasi dan pendekatan kepada masyarakat untuk memberikan pemahaman mengenai pentingnya untuk melakukan tindakan yang preventif terhadap penyebaran virus ini. Pemerintah harus mampu memberikan jawaban atas kekhawatiran masyarakat dengan adanya pembatasan sosial baik skala kecil maupun skala besar.

Saat ini, berbagai dampak sosial dan ekonomi pembatasan sosial tidak dapat dipungkiri mulai nampak di masyarakat. Peran pemerintah pusat dan daerah dalam hal ini menjadi sangat penting untuk mengambil keputusan-keputusan cepat dan 
tepat untuk mengatasi penyebaran virus ini. Pembatasan sosial skala besar berdasarkan Keppres yang telah diterbitkan dapat dilaksanakan setelah adanya persetujuan Menteri Kesehatan yang mempertimbangkan tingkat penyebaran virus yang besar di suatu daerah. Hal ini perlu untuk evaluasi kembali karena apabila pembatasan skala besar dilakukan setelah jumlah terinfeksi semakin besar maka akan menjadi tidak efektif karena waktu yang dibutuhkan untuk menunggu jumlah yang memenuhi syarat untuk dapat diberikan izin memberlakukan PSBB sama dengan menunggu semakin banyak warga yang terinfeksi.

Berbicara mengenai karantina kesehatan seharusnya pemerintah mendasarkan pada Undang-undang Nomor 6 Tahun 2018 tentang Kekarantinaan Kesehatan, sebagaimana telah terdapat istilah karantina yang diatur pada pasal 49. Pada Undang-Undang Nomor 6 Tahun 2018 tentang Kekarantinaan Kesehatan, disebutkan bahwa "selama dalam Karantina Wilayah, kebutuhan hidup dasar orang dan makanan hewan ternak yang berada di wilayah karantina menjadi tanggung jawab Pemerintah Pusat". Penerapan Darurat Sipil juga bertentangan dengan asas hukum lex specialis derogat legi generalis, yakni hukum yang khusus dapat mengenyampingkan hukum yang umum. Undang-Undang tentang Kekarantinaan Kesehatan lebih khusus membahas tentang kesehatan dan lebih sesuai dengan bencana yang dihadapi sekarang dibandingkan dengan Perppu Penetapan Keadaan Bahaya. Belakangan, sebagai pilihan pengendalian, pemerintah menerbitkan PP Nomor 21 Tahun 2020 tentang Pembatasan Sosial Berskala Besar (PSBB). PP ini berisi pelaksanaan sebagian isi Undang-Undang tentang Kekarantinaan Kesehatan, khususnya mengenai PSBB, tidak mengenai materi yang lain. Artinya, seperti kebutuhan hidup orang dan makanan hewan ternak masih menjadi tanggung jawab sendiri.

\section{KESIMPULAN}

Dalam membentuk peraturan perundang-undangan harus dilakukan berdasarkan asas pembentukan peraturan perundang-undangan yang baik meliputi: kejelasan tujuan, kelembagaan atau pejabat pembentuk yang tepat dan kesesuaian antara jenis, hierarki serta materi muatan yang dapat dilaksanakan dan kedayagunaan serta kehasilgunaan, kejelasan rumusan dan keterbukaan. Di samping itu materi muatan yang dimuat dalam peraturan perundang-undangan harus mencerminkan asas pengayoman, kemanusiaan dan kebangsaan serta kekeluargaan, kenusantaraan, bhinneka tunggal ika, keadilan serta kesamaan kedudukan dalam hukum dan pemerintahan, ketertiban dan kepastian hukum serta keseimbangan, keserasian, dan keselarasan. Asas-asas pembentukan peraturan perundang-undangan di atas mencerminkan bentuk peraturan perundang-undangan yang baik. Jika itu diterapkan ke dalam suatu peraturan perundang-undangan, maka akan terbentuk suatu peraturan perundangundangan yang baik yang sesuai dengan asas-asas yang sudah tercantum di dalam undang-undang tanpa meninggalkan prinsip-prinsip keadilan. 


\section{DAFTAR PUSTAKA}

https://megapolitan.kompas.com/read/2020/03/02/15001891/menkes-kalau-imunitasbaik-tubuh-kebal-virus-corona?page=all diakses pada tanggal 20 juli 2020 .

Instruksi Presiden Nomor 4 Tahun 2020 tentang Recofusing Kegiatan, Relokasi Anggaran serta Pengadaan Barang dan Jasa Dalam Rangka Percepatan Penanganan Corona Virus Disease 2019 (COVID-19).

Keputusan Presiden Nomor 7 Tahun 2020 tentang Gugus Tugas Percepatan Penanganan Corona Virus Disease 2019.

Keputusan Presiden Nomor 9 Tahun 2020 tentang Perubahan atas Keputusan Presiden Nomor 7 Tahun 2020 tentang Gugus Tugas Percepatan Penanganan Corona Virus Disease 2019.

Keputusan Presiden Republik Indonesia Nomor 11 Tahun 2020 Tentang Penetapan Kedaruratan Kesehatan Masyarakat Corona Virus Disease 2019.

Keputusan Presiden Nomor 12 Tahun 2020 tentang Penetapan Bencana Nonalam Penyebaran Corona Virus Disease 2019 (COVID-19).

Peraturan Pemerintah Nomor 21 Tahun 2020 tentang Pembatasan Sosial Berskala Besar Dalam Rangka Percepatan Penanganan Corona Virus Disease 2019.

Peraturan Pemerintah Pengganti Undang-Undang Republik Indonesia Nomor 1 Tahun 2020 Tentang Kebijakan Keuangan Negara Dan Stabilitas Sistem Keuangan Untuk Penanganan Pandemi Corona Virus Disease 2019 (Undang-undang Nomor 2 Tahun 2020).

Peraturan Menteri Hukum dan HAM 11 Tahun 2020 tentang Pelarangan Sementara Orang Asing Masuk Wilayah NKRI.

Peraturan Menteri Keuangan Nomor 23/PMK.03/2020 tentang Insentif Wajib Pajak Terdampak Wabah Virus Corona.

Peraturan Menteri Kesehatan Nomor 9 Tahun 2020 tentang Pedoman Pembatasan Sosial Berskala Besar Dalam Rangka Percepatan Penanganan Corona Virus Disease (COVID-19).

Soerjono Soekanto dan Sri Mamudji. (2015).Penelitian Hukum Normatif, Suatu Tinjauan Singkat Cetakan Kelima belas.Jakarta: Rajawali Pers

Sadhu Bagas Suratno. (2017). Pembentukan Peraturan Kebijakan Berdasarkan AsasAsas Umum Pemerintahan yang Baik, e-Journal Lentera Hukum, Volume 4, Issue 3 (2017), pp. 164-174 doi: 10.19184/ejlh.v4i3.5499 @ University of Jember, 2017 Published online 10 December 2017.

Undang-Undang Dasar Negara Republik Indonesia Tahun 1945 setelah amandemen. 
Seminar Nasional Penelitian dan Pengabdian kepada Masyarakat

Undang-undang Nomor 30 Tahun 2014 tentang Administrasi Pemerintahan.

Undang-undang Nomor 6 Tahun 2018 tentang Kekarantinaan Kesehatan. 